\title{
A morphometric analysis of Eunice Cuvier (Annelida, Polychaeta) species
}

\author{
Elisa M. Costa-Paiva \& Paulo C. Paiva
}

Departamento de Zoologia, Instituto de Biologia, Universidade Federal do Rio de Janeiro. Bloco A, Ilha do Fundão, 21940-590 Rio de Janeiro, Rio de Janeiro, Brasil. E-mail: elisapolychaeta@hotmail.com

\begin{abstract}
Morphology has been the subject of several studies in Eunice specially in the context of the taxonomy and evolutionary relationships of taxa within this genus. In this study we opt for a morphometric approach comparing five species of Eunice to assess if it was possible to delimitate them by shape variables. The morphology of E. fucata, E. insularis, E. cf. ornata, E. rubra, and Eunice sp. was compared using traditional morphometric analysis of 16 measured variables. After removing the size-effect, a Canonical Variates Analysis applied to morphometric variables was able to discriminate all species. In CV1 two major groups of species were discriminated: E.fucata / E. insularis and E. cf. ornata / E. rubra/ Eunice sp. CV2 strongly discriminated all species, with $E$. cf. ornata with higher scores and $E$. rubra with lower ones. The characters that differentiate the species were the relative size of antennae, peristomium and anteriormost setigers. This study also demonstrated that peristomium width and palps length were the best variables for body size estimation in Eunice, since they were highly correlated to the size-estimator. Through morphometric analysis it was possible to delimitate species and choose diagnostic characters for the genus Eunice, a result likely to be valid for other polychaete species. KEY WORDS. Body-size; eunicid; morphometry; multivariate analysis; taxonomy.
\end{abstract}

RESUMO. Um estudo morfométrico de espécies de Eunice Cuvier (Annelida, Polychaeta). Estudos morfológicos em Eunice são muito comuns, especialmente em um contexto taxonômico e de relações evolutivas de táxons deste gênero. Neste estudo, optamos por uma abordagem morfométrica comparando cinco espécies de Eunice para avaliar a possibilidade de delimitá-las através de variáveis de forma. A morfologia de $E$. fucata, $E$. insularis, $E$. cf. ornata, E. rubra e Eunice sp. foi comparada utilizando-se análises de morfometria tradicional de 16 variáveis mensuradas. Após a remover o efeito de tamanho, uma Análise de Variáveis Canônicas aplicada às variáveis morfométricas permitiu a discriminação de todas as espécies. Em CV1, dois grupos maiores de espécies foram discriminadas: E.fucata/E. insularis e $E$. cf. ornata/E. rubra/Eunice sp. CV2 discriminou fortemente todas as espécies com $E$. cf. ornata apresentando escores maiores e $E$. rubra os menores. Os caracteres que diferenciaram as espécies foram o tamanho relativo das antenas, do peristômio e dos setígeros anteriores. Este estudo também demonstrou que a largura do peristômio e o comprimento dos palpos são as melhores variáveis para estimar o tamanho do corpo em Eunice, já que ambas estiveram altamente correlacionadas com o estimador de tamanho. Através de análises morfométricas foi possível delimitar as espécies e escolher caracteres diagnósticos para o gênero Eunice, um resultado provavelmente válido para outras espécies de poliquetas.

PALAVRAS-CHAVE. Análise multivariada; eunicídeos; morfometria; tamanho do corpo; taxonomia.

RoHLF (1990) postulated that morphometrics - the quantitative description and analysis, as interpretation of shape and shape variation in biology - was a fundamental area of research. Body shape represents an important set of animal characters that are used for particular comparative purposes, such as studies of taxonomy, ecology, evolution, growth and presence of abnormalities (Bookstein 1982, Lestrel 2000, Zelditch et al. 2004). In taxonomic research morphometrics can be used to provide new sets of characters when regular qualitative morphology is not enough to distinguish taxa. Several taxonomic studies have used multivariate analysis with success to detect and evaluate subtle differences among closely related species (JORDAENs et al. 2002, BeCERRA \& VALDECASAS 2004) and even among populations (Debuse et al. 2001, Martin et al. 2003).

Previous papers on morphometric studies with polychaete worms indicated that certain morphological characters of polychaetes vary in a size-dependent way (SigvaldadotTiR \& MackiE 1993, Ben-Eliahu 1987, Fauchald 1991). Therefore, when possible, a statistical study is highly recommended, because it will not only help clarify relations among similar species but will also help to identify phylogenetically important characters, and may also yield ecologically interpretable results (Lu \& FAUCHALD 1998). 
The morphology of Eunice Cuvier, 1817, a common polychaete worm, has been the subject of several studies, especially in the context of the taxonomy and evolutionary relationships of the taxa within this genus (Fauchald 1992). In the present study the morphological characteristics of some species of Eunice were analyzed using morphometric variables. Such variables were compared among five populations of different species of Eunice using multivariate statistics. Some of this variables are normally used in the taxonomy of the genus as proportions or ratios (e.g. relative size of antennae, palps, cirri, prostomium and peristomium) a procedure that does not incorporate allometric variation of characters during ontogeny. Thus, differentiation of species based upon such ratios are likely to provide misleading results when comparing species of different age structure.

The aim of this study is to demonstrate if these five populations can be distinguished using information from morphometric data. Most of the species included in our study were chosen a priori, such as E. fucata Ehlers, 1887; E. insularis Nogueira, Steiner \& Amaral, 2000; E. cf. ornata Andrews, 1891 and E. rubra Grube, 1856. Besides, in order to reveal the right identity of Eunice sp., this species was also included in the analysis. Furthermore, this study will present which of the scored characters are the most useful morphological features for size estimation and taxonomy of this genus.

\section{MATERIAL AND METHODS}

\section{Sampling}

A total of 81 specimens were analyzed, distributed among five different species: 1) Eunice fucata Ehlers, 1887 - eight specimens associated with calcareous algae from Abrolhos Archipelago (Bahia State, Brazil) and from the continental shelf of eastern Brazilian coast; 2) Eunice insularis Nogueira, Steiner \& Amaral, 2000 - 30 specimens from Todos os Santos Bay (Bahia State, northeastern Brazilian coast); 3) Eunice cf. ornata Andrews, 1891 - 20 specimens from the continental shelf of eastern Brazilian coast; 4) Eunice rubra Grube, 1856 - nine specimens of shallow rocky coasts, associated to algae and ascidians from Ubatuba (São Paulo State, southern Brazilian coast); (5) Eunice sp. - 14 specimens from Todos os Santos Bay (Bahia State, eastern Brazilian coast).

The specimens of $E$. rubra were previously anesthetized with isotonic magnesium chloride and further fixed in $10 \%$ formalin. The other specimens were directly fixed in $10 \%$ formalin without previous anesthetization. All the specimens were preserved in $70 \%$ ethanol after fixation and deposited at the Departamento de Zoologia, Instituto de Biologia, Universidade Federal do Rio de Janeiro (IBUFRJ) collection (E. fucata, IBUFRJ 0040 to $0045 ;$ E. insularis, IBUFRJ 0628; E. cf. ornata, IBUFRJ 0629; E. rubra, IBUFRJ 0630; Eunice sp., IBUFRJ 0631). Only complete and not damaged specimens were used in the analyses.

\section{Data collection}

All variables used for morphometric analysis were measured under a graduate stereoscopy microscope (Zeiss Stemi SV 11) being listed below (abbreviations provided in brackets) 25 morphometric features were measured, however only 16 were used in the analysis (Fig. 1): I) total length minus length to setiger 10 - length was measured from the tip of the prostomium to the end of the pygidium, omitting antennae and anal cirri (FAUCHALD 1992). Since length through setiger 10 is another feature, this was subtracted from the total length giving the corrected total length (TL); II) length to setiger 10 (L10); III) length of prostomium - length was measured in the lobe of the prostomium, omitting the median sulcus (LPR); IV) length of peristomium (LPE); V) width of prostomium (WPR); VI) width of peristomium (WPE); VII) length of peristomial cirri - this value was obtained from the average of all cirri measurements (LPC); VIII) length of dorsolateral palps sensu ORRHAGE (1995) - formerly considered as an additional pair of antennae. This value was obtained from the average of all palps measurements (LDP); IX) length of lateral antennae - this value was obtained from the average of all antennae measurements (LLA); X) length of central antenna (LCA); XI) length of setiger 10 (LS10) - the choice of an anterior setiger was based on a comparison with other setigers (setiger 5 and 20), whose measurements provided similar patterns; XII) length of setiger 50 (LS50) - the choice of a median setiger was based on a comparison with another setiger (setiger 100), whose measurements provided a similar pattern; XIII) depth of setiger 10 - depth was measured with the specimen laid in a lateral position (DS10); XIV) depth of setiger 50 - depth was measured with the specimen laid in a lateral position (DS50); XV) width of setiger 10 (WS10); XVI) width of setiger 50 (WS50).

Excluded variables were those autocorrelated or highly correlated to other included variables, i.e. length to setiger 5, 20 and 50 (all correlated to length to setiger 10); length, depth and width of setigers 5 and 20 (correlated to length, depth and width of setiger 10 and 50 respectively).

\section{Data analysis}

A size-free Canonical Variates Analysis (CVA) was applied to the set of data, that were previously log-transformed ( $y=\log$ ${ }_{2}$ ) in order to obtain the linear form (SOKAL \& RHOLF 1994). The effect of size was previously removed by regressing each morphometric variable on the first principal component obtained by a Principal Component Analysis (PCA), considered here as a multivariate size estimate (STrauss 1985, Reis et al. 1990). The residuals obtained after regression, expressing size-free variation, were submitted to the Canonical Variates Analysis. PCA was based on the pooled variation using a covariance matrix of morphometric data.

The importance of each character for discriminating among species was evaluated by a correlation (Pearson product-moment coefficient) between individual scores of canonical variates and the values of characters for each individual (STRAUSS 1985). The probability of each correlation coefficient $(\mathrm{p}<0.05)$ was calculated by Bonferroni method using SYSTAT 10.0 software procedures. An ANOVA (Analysis of Variance) was also applied to the canonical variates to test among-species variation, being submitted, a posteriori, to a Tukey test. 


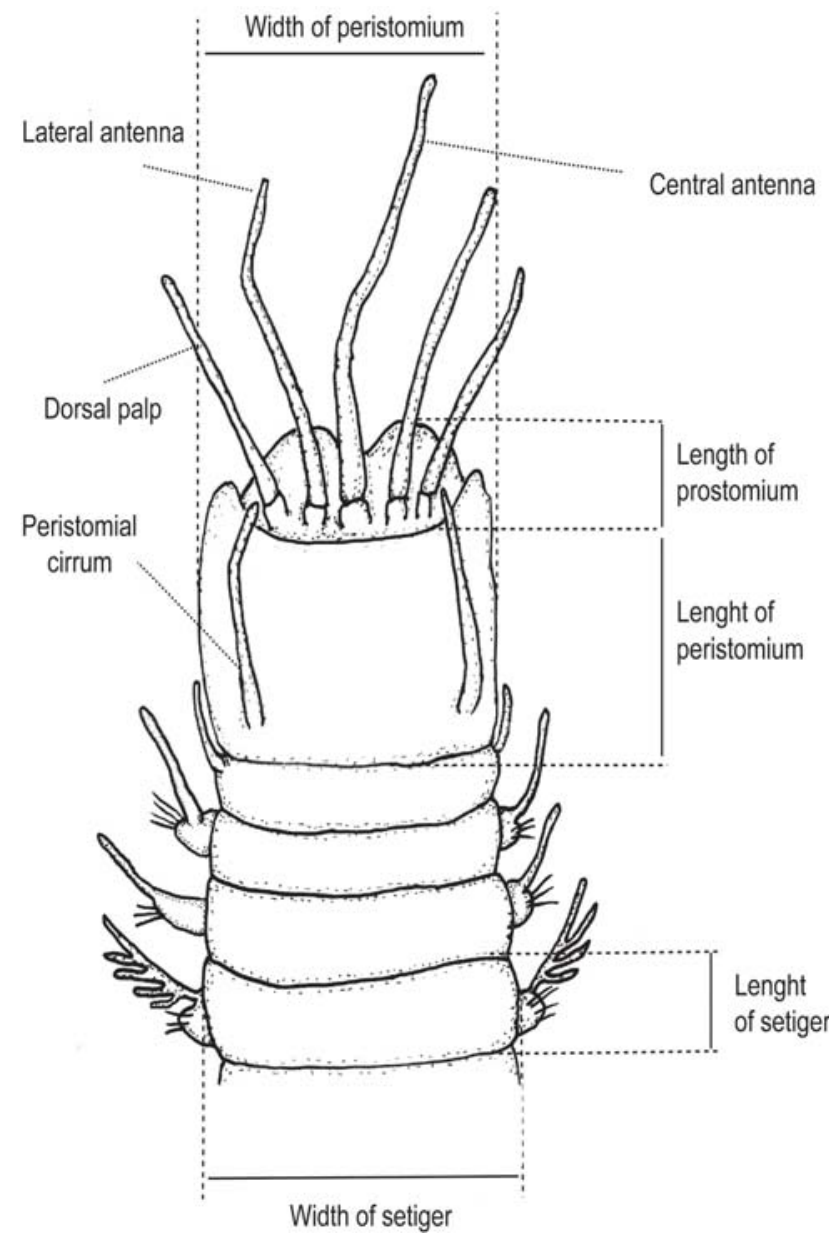

Figure 1. Anterior region of Eunice spp. showing morphometric measured variables.

To assess which morphometric variables are better for describing size, correlations were performed between the sizeestimator, the first principal component (PC1), and each variable by Pearson product-moment.

\section{RESULTS}

\section{Size estimation}

The variables that better represent body size, assessed by correlations to size-estimator are presented in table I. Width of peristomium (WPE), length of dorsolateral palps (LDP), length of peristiomial cirri (LPC), length of lateral antennae (LLA) and depth of setiger 10 (DS10) seem to be the best variables, all of them presenting correlations coefficients above 0.94 being located in the anteriormost part of the body. Other variables presented relative high correlations, above 0.80 , except for total length (TL) with only 0.627 .

\section{Species discrimination}

Size-effect, assessed by first principal component, was responsible for $75 \%$ of the variation in the PCA of morphometric measurements showing the large size-range of studied specimens.

In the Canonical Variates Analysis, applied after removing the size-effect by means of PCA, the first canonical variate (CV1) was responsible for $65 \%$ of the variation among-groups, the second (CV2) for 21\%, CV3 for $13 \%$ and the remaining CV4 for only $1 \%$. Results of CVA indicated significantly among populations differences (Wilks $\Lambda=0.062, \mathrm{~F}_{[60,244]}=4.24, \mathrm{p}<0.0001$ ) confirming the visual observation of the plots of the canonical variates. The mean percentage of specimens correctly classified to original populations was relatively high $(85 \%)$, with correctly assignment for each population ranging from $75 \%$ for $E$. fucata to $100 \%$ for E. rubra and Eunice sp.

The plot of the canonical variates 1 and 2 shows a strong discrimination of species scores in two main groups along CV1: $E$. fucata and $E$. insularis with higher scores and $E$. cf. ornata, $E$. rubra and Eunice sp. with lower ones (Fig. 2). An ANOVA applied for scores of each species and an a posteriori Tukey test showed that even within these main groups it was possible to discriminate the species $\left(\mathrm{F}_{[4]}=65.43, \mathrm{p}<0.001\right)$. Only two species, $E$. cf. ornata and Eunice sp., were not distinguishable in CV1 (Fig. 3).

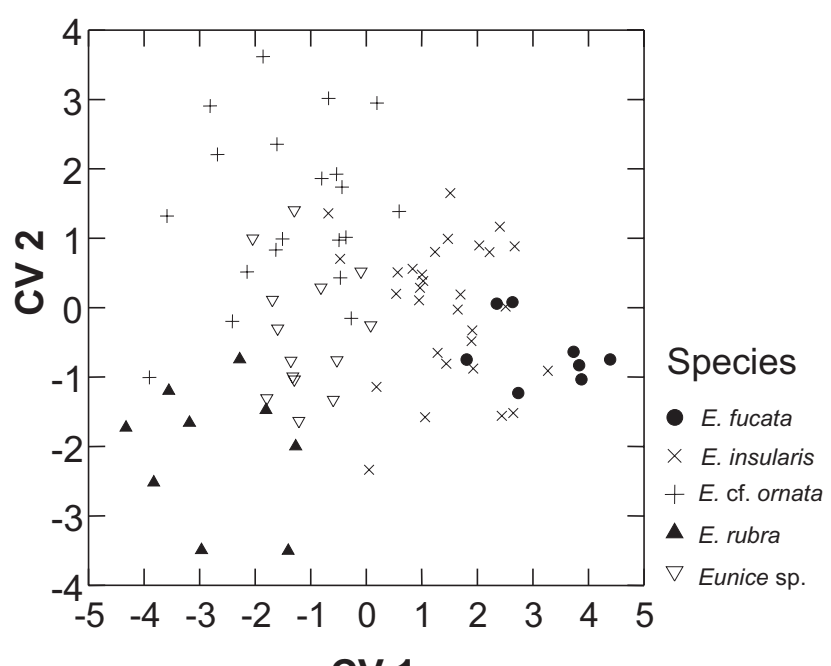

CV 1

Figure 2. Plot of species scores for the two first canonical variates.

CV2 strongly discriminated all species, with $E$. cf. ornata with higher scores and E. rubra with lower ones. The other species presented intermediate scores, but where also significantly different among them $\left(\mathrm{F}_{[4]}=24.86, \mathrm{p}<0.001\right)$ (Figs 2 and 3). CV3 discriminated only Eunice sp. from all other species $\left(\mathrm{F}_{[4]}=\right.$ $12.24, \mathrm{p}<0.001)$, no other significant differences were observed among species in this canonical variate (Figs 3 and 4).

Revista Brasileira de Zoologia 24 (2): 353-358, junho 2007 


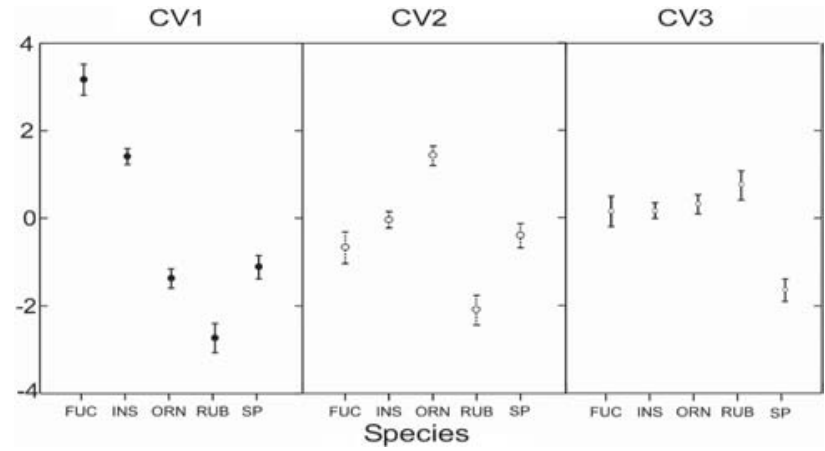

Figure 3. Mean score of species for each canonical variate (CV) plus confidence interval (95\%). Overlapping of confidence intervals bars indicates no significant differences in the pairwaise Tukey test.

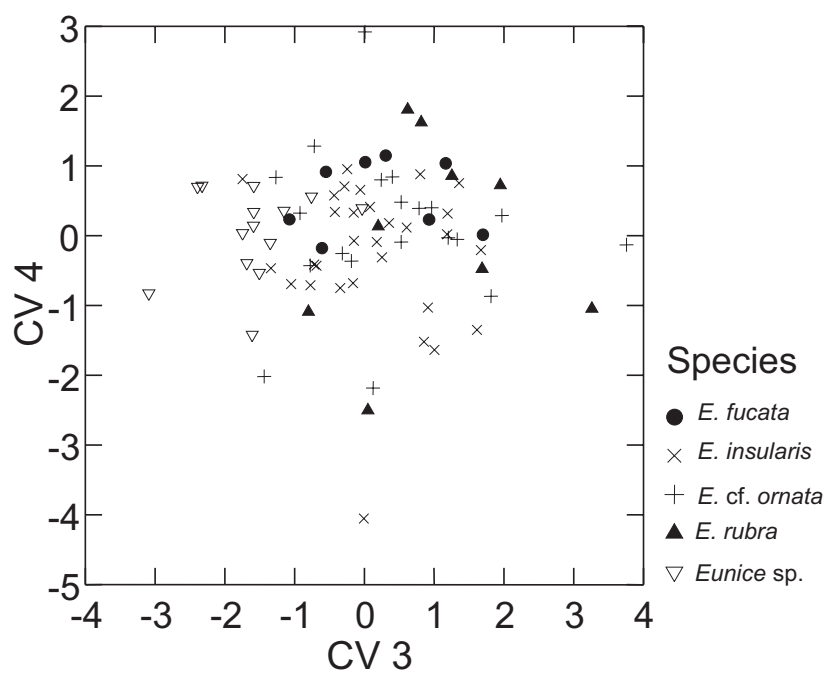

Figure 4. Plot of species scores for the third and fourth canonical variates.

\section{Shape differences among species}

The first canonical variate (CV1) was significantly correlated $(\mathrm{p}<0.05)$ to nine out of 16 measured characters, CV2 was correlated to four characters, and CV3 to five characters (Tab. I). Discrimination between main groups of species for CV1 was based mainly on the length of antennae (LLA, LCA); width of prostomium (WPR), relative size of setigers (LS10, DS10, DS50, WS50), and length of anteriormost part of the body (L10). Antennae and anteriormost part of the body are more developed in the E. cf. ornata, E. rubra and Eunice sp. than in E. fucata and E. insularis, which present wider and deeper median setigers and wider prostomium.

Eunice rubra, with lower scores in CV2, presented more elongated anteriormost setigers and longer peristomium, expressed by the negative correlation between CV2 and the length of setigers 10 (LS10) and peristomium (LPE). Whereas E. cf.
Table I. Pearson correlation between morphometric variables body-size estimator and canonical variates. Values in bold are significative at 0.05 level.

\begin{tabular}{lcrrr}
\hline Variables & Body-size estimator & CV1 & CV2 & CV3 \\
\hline TL & 0.627 & 0.343 & -0.194 & 0.121 \\
L10 & 0.893 & $-\mathbf{0 . 6 5 2}$ & -0.114 & $\mathbf{0 . 5 0 2}$ \\
LPR & 0.852 & -0.169 & -0.156 & $\mathbf{0 . 4 5 2}$ \\
LPE & 0.931 & -0.091 & $-\mathbf{0 . 4 4 4}$ & 0.352 \\
WPR & 0.834 & $\mathbf{0 . 6 7 8}$ & 0.256 & 0.308 \\
WPE & $\mathbf{0 . 9 6 3}$ & 0.355 & 0.286 & 0.166 \\
LPC & $\mathbf{0 . 9 5 5}$ & -0.162 & -0.013 & $-\mathbf{0 . 6 1 1}$ \\
LDP & $\mathbf{0 . 9 6 2}$ & -0.254 & 0.106 & $-\mathbf{0 . 3 7 5}$ \\
LLA & $\mathbf{0 . 9 4 6}$ & $-\mathbf{0 . 6 0 8}$ & $\mathbf{0 . 5 3 5}$ & -0.213 \\
LCA & 0.912 & $-\mathbf{0 . 6 9 6}$ & $\mathbf{0 . 4 4 3}$ & -0.183 \\
LS10 & 0.818 & $-\mathbf{0 . 5 3 6}$ & $-\mathbf{0 . 4 6 7}$ & $\mathbf{0 . 4 5 2}$ \\
LS50 & 0.840 & -0.228 & -0.223 & 0.147 \\
DS10 & $\mathbf{0 . 9 4 5}$ & $\mathbf{0 . 4 9 0}$ & 0.135 & -0.062 \\
DS50 & 0.827 & $\mathbf{0 . 4 9 7}$ & 0.268 & 0.116 \\
WS10 & 0.918 & $\mathbf{0 . 5 9 4}$ & -0.128 & -0.119 \\
WS50 & 0.864 & $\mathbf{0 . 5 2 4}$ & -0.335 & -0.095 \\
\hline
\end{tabular}

ornata, with higher scores, presented shorter peristomium, shorter anteriormost setigers, and longer antennae.

Eunice sp. was discriminated for all other species in CV3 with lower scores. This discrimination owing to the shorter prostomium (LPR), longer peristomial cirri and dorsolateral palps (LPC, LDP) of Eunice sp.

\section{DISCUSSION}

Taxonomy of Eunice and of polychaetes in general is based mainly in meristic characters, relative measures of structures and qualitative expressions of shape (Rouse \& Pleijel 2001). Sometimes shape depends on the observer point of view, even though it can be formally described in a less subjective way by means of some numerical or mathematical functions (STEVENS 1991). Such functions, assessed by means of morphometrical analysis allowed the discrimination of the species of Eunice analyzed herein. Three species (E. fucata, E. insularis and E. rubra) were significatly differentiated among themselves and from the group E. cf. ornata/Eunice sp., in CV1 with this last pair being further discriminated in CV2, allowing a complete delimitation by shape of all studied species.

Eunice sp. was the only taxon not identified a priori in the specific level, owing to the presence in this species of a combination of traditional characters of both E. rubra and $E$. cf. ornata. These species are usually confounded in several taxonomic studies owing to morphological similarities (for a revision see Fauchald 1992). These similarities emerged in the morphometric analysis with the negative scores of these three spe- 
cies in CV1 contrasting with the positive ones for E. insularis and $E$. fucata. The complete discrimination of all species in the complete analysis and the correctly a posteriori assignment of all its individuals to its original group in CVA confirm that Eunice sp. is an entity apart from both E. rubra and E. cf. ornata. Since size is a consequence of growth and growth in polychaetes is achieved by segments increment, number of segments could be considered a realistic size estimator. Nevertheless, Eunicidae specimens commonly present the ability of autotomy and a great regeneration power (ORENSANZ 1975), making invalid the use of such variable as a size estimate. The analysis of linear combination of several morphometric variables by means of principal component analysis, after log-tranformation of raw data, is a more realistic size estimate. Nevertheless, some parametric measures for routine size estimation are advisable, such as width of peristomium (WPE) and length of dorsolateral palps (LDP) which showed the highest correlation coefficients to size component and being more easily measurable owing to its anteriormost body location. These measurements seem to be subjected to less measurement errors (e.g. Bailey \& Byrnes 1990) and preservation methods than more flexible structures such as setigers. Total length (TL), a variable normally used in population dynamics studies seems to be, at least in Eunice, not a good descriptor of size, as shown by the lowest correlation of this variable to PC1. This result is probably related to propagation of measurements errors from several individual setigers, mainly when considering that median and posterior setigers are devoid of strong muscles (Paxton 2000), being so more soft and suitable to deformation owing to fixation procedures. Besides, it is rather difficult to obtain complete specimens in collections when standard sampling procedures where used (GIANGRANDE 1989).

These analysis also showed which measured characters are more helpful in the taxonomy of the genus Eunice. For instance, characters such as relative size of antennae and prostomium width, available even for incomplete specimens, showed to differentiate species of this genus, demonstrating how useful they could be in species diagnosis of the genus. Morphometric analysis was effective both for delimitation of species and choice of diagnostic characters for the genus Eunice, being so a useful tool for taxonomic studies of polychaetes and probably of other softbodied animals.

\section{ACKNOWLEDGEMENTS}

We are grateful to Leila Pêssoa, Blanché Bitner-Mathé Leal, and Joana Zanol for their critical reading of the manuscript. Financial support was provided by Fundação de Amparo a Pesquisa do Estado do Rio de Janeiro - Process: E-26/151.609/2001 and Coordenadoria de Aperfeiçoamento de Pessoal de Nível Superior.

\section{REFERENCES}

Bailey, R.C. \& J. Byrnes. 1990. A new, old method for assessing measurement error in both univariate and multivariate morphometric studies. Systematic Zoology 39: 124-130.
BeCERRA, J.M. \& A.G. VALDECASAS. 2004. Landmark superimposition for taxonomic identification. Biological Journal of the Linnean Society 81: 267-274.

Ben-Eliahu, M.N. 1987. An approch to nereidid morphometry. Bulletin of the Biological Society of Washington 7: 169173.

Bookstein, F.L. 1982. Foundations of Morphometrics. Annual Review of Ecology and Systematics 13: 451-470.

Debuse, V.J.; J.T. Addison \& J.D. Reynolds. 2001. Morphometric variability in UK populations of the European lobster. Journal of the Marine Biological Association of the United Kingdom 81: 469-474.

Fauchald, K. 1991. A morphometric study of eunicid polychaetes from Belize, Western Caribbean Sea. Ophelia 5: 47-53.

Fauchald, K. 1992. A review of the genus Eunice (Polychaeta: Eunicidae) based upon type material. Smithsonian Contributions to Zoology 523: 1-422.

Giangrande, A. 1989. Observations on recruitment and growth of Eunice harassii Audouin e Milne Edwards (Polychaeta, Eunicidae) in the Mediterranean Sea. Vie et Milieu 39: 135-141.

Jordaens, K.; S. van Dongen; P. Van Riel; S. Geenen; R. Verhagen \& T. BACKELJAU. 2002. Multivariate morphometrics of soft body parts in terrestrial slugs: comparison between two datasets, error assessment and taxonomic implications. Biological Journal of the Linnean Society 75: 533-542.

LestreL, P.E. 2000. Morphometrics for the life sciences. Singapore, World Scientific Publishing, 261p.

Lu, H. \& K. Fauchald. 1998. Description of Eunice weintraubi and E. wui, two new species of eunicid polychaetes from northern Gulf of Mexico. Proceedings of the Biological Society of Washington 111: 230-240.

Martin, D.; T.A. Britayev; G. SAN Martín \& J. Gil. 2003. Inter-population variability and character description in the spongeassociated Haplosyllis spongicola complex (Polychaeta: Syllidae). Hydrobiologia 496: 145-162.

Orensanz, J.M. 1975. Los anélidos poliquetos de la provincia biogeográfica Argentina. 7. Eunicidae y Lysaretidae. Physis A 34: 85-111.

OrRhage, L. 1995. Appendages of the Eunicea (Polychaeta), with a tentative outline of the fundamental constitution of the cephalic nervous system of the polychaetes. Acta Zoologica 76: $229-248$.

Paxton, H. 2000. Family Eunicidae, p. 94-96. In: P.L. Beesley; G.J.B. Ross \& C.J. Glasby (Eds). Polychaetes and Allies: the southern sysnthesis. Fauna of Australia. Melbourne, CSIRO Publishing, vol. 4a, XII+465p.

Reis, S.F.; L.M. Pessôa \& R.E. Strauss. 1990. Application of sizefree canonical discriminant analysis to studies of geographic diferentiation. Brazilian Journal of Genetics 13: 509-520.

Rohlf, F.J. 1990. Morphometrics. Annual Review of Ecology and Systematics 21: 299-316.

Rouse, G.W. \& F. Pleijel. 2001. Polychaetes. New York, Oxford University Press, XIII+354p.

Revista Brasileira de Zoologia 24 (2): 353-358, junho 2007 
Sigvaldadottir, E. \& A.S.Y. Mackie. 1993. Prionospio steenstrupi, $P$. fallax and $P$. dubia (Polychaeta: Spionidae): re-evaluation of identity and status. Sarsia 78: 203-219.

SOKAL, R.R. \& F.J. Rholf. 1994. Biometry. San Francisco, Freeman, $\mathrm{XIX}+887 \mathrm{p}$.

Stevens, P.F. 1991. Character states, morphological variation, and phylogenetic analysis: a review. Systematic Botany 16:
553-583.

STRAUSS, R.E. 1985. Static allometry and variation in body form in the South American catfish genus Corydoras (Callichthyidae). Systematic Zoology 34: 381-396.

Zelditch, M.L.; D.L. Swiderski; H.D. Sheets \& W.L. Fink. 2004. Geometric morphometrics for biologists: a primer. San Diego, Elsevier Academic Press, 443p.

Received in 09.V.2006; accepted in 01.V.2007.

Revista Brasileira de Zoologia 24 (2): 353-358, junho 2007 